\title{
Mineralogy and petrology of lunar meteorite Northwest Africa 2977 consisting of olivine cumulate gabbro including inverted pigeonite
}

Hiroshi Nagaoka ${ }^{1,2^{*}}$, Yuzuru Karouji ${ }^{3}$, Hiroshi Takeda ${ }^{4}$, Timothy J. Fagan ${ }^{5}$, Mitsuru Ebihara ${ }^{6}$ and Nobuyuki Hasebe ${ }^{1,2}$

\begin{abstract}
Lunar meteorite Northwest Africa (NWA) 2977 is identified as an olivine cumulate gabbro (OC), consisting of coarse cumulate olivine crystals up to $1 \mathrm{~mm}$ with low-Ca and high-Ca pyroxenes, plagioclase, and interstitial incompatible element-rich pockets of K-feldspar, Ca-phosphates, ilmenite, and troilite. These minerals and textures are similar to those of the OC clasts of the NWA 773 clan of meteorites. NWA 2977 contains a variety of pyroxene textures and compositions including augite, pigeonite, and rare orthopyroxene, all having exsolution lamellae. Some of the orthopyroxene has abundant augite lamellae with compositions indicating formation by inversion of pigeonite. This pigeonite was inverted at $1140{ }^{\circ} \mathrm{C}$ according to the pigeonite eutectoid reaction (PER) temperatures. Inverted pigeonite has not been found previously in the NWA 773 clan of meteorites. The presence of inverted pigeonite indicates that NWA 2977 cooled more slowly than most other OC clasts of the NWA 773 clan. The relatively slow cooling of NWA 2977 can be explained by formation in a deeper level of the original igneous body of the NWA 773 clan OC lithology.
\end{abstract}

Keywords: Moon, Mare basalt, Lunar meteorite, Mineralogy, Pyroxene, Inverted pigeonite

\section{Background}

Apollo and Luna mare basalt samples indicate that lunar mare volcanism was active at least from 4.3 to 3.2 Ga, after feldspathic crustal formation (e.g., Spudis and Pieters 1991; Nyquist and Shih 1992; Shearer et al. 2006). However, the radiogenic ages of basaltic lunar meteorites extend the duration of mare volcanism to younger ages $\leq 3 \mathrm{Ga}$. Borg et al. (2009) reported Nd-Sm crystallization ages of $2.993 \pm 0.032 \mathrm{Ga}$ for an olivine cumulate gabbro (OC) clast from the basaltic breccia Northwest Africa (NWA) 773 and $2.931 \pm 0.092 \mathrm{Ga}$ for mare basalt NWA 032; Wang et al. (2012) gave a $\mathrm{Pb}-\mathrm{Pb}$ crystallization age of 3.073 $\pm 0.015 \mathrm{Ga}$ for $\mathrm{Zr}$-rich minerals in mare basalt NWA

\footnotetext{
*Correspondence: hiroshi-nagaoka@asagi.waseda.jp

${ }^{1}$ Research Institute for Science and Engineering, Waseda University, Shinjuku, Tokyo 169-8555, Japan

${ }^{2}$ School of Advanced Science and Engineering, Waseda University, Shinjuku, Tokyo 169-8555, Japan

Full list of author information is available at the end of the article
}

4734; Anand et al. (2006) reported a U-Pb age of $2.929 \pm 0.15 \mathrm{Ga}$ for phosphates in mare basalt LaPaz Icefield (LAP) 02205. These younger ages are consistent with the model ages based on crater counts from mare surfaces (Hiesinger and Head 2006). The presence of mare surfaces younger than $\leq 3 \mathrm{Ga}$ has been verified by Morota et al. (2011) in the Procellarum KREEP Terrane (PKT), where incompatible elements such as $\mathrm{K}, \mathrm{Th}$, and $\mathrm{U}$ and rare earth elements (REE) are highly concentrated (Jolliff et al. 2000). Meteoritic and remote sensing data also include geochemical and petrological information not obtained from the samples returned from the Apollo missions (e.g., Jolliff et al. 2000; Korotev 2005; Nagaoka et al. 2014; Ohtake et al. 2012). These young basaltic lunar meteorites could provide a key to understanding the petrogenesis of younger mare volcanism.

Lunar meteorite NWA 2977 is an OC that is texturally and mineralogically similar to the OC clasts found in the NWA 773 clan (e.g., Bunch et al. 2006; Fagan et al. 2003; Jolliff et al. 2003; Zhang et al. 2011). 
Whereas the NWA 773 meteorite contains the OC lithology as clasts in a breccia, NWA 2977 is a 233-g stone consisting entirely of OC (Connolly et al. 2006). Previous studies, including our work, have used minerals and textures to conclude that the $\mathrm{OC}$ of NWA 2977 is part of the NWA 773 clan (Bunch et al. 2006; Nagaoka et al. 2010, 2011; Zhang et al. 2011). In addition to their petrologic affinities, NWA 2977 and NWA 773 both have bulk rock chemical compositions with similar KREEP-like REE patterns (Fagan et al. 2003; Jolliff et al. 2003; Nyquist et al. 2009; Zhang et al. 2011). The pairing of NWA 2977 with NWA 773 is supported further by similar isotopic ages that are relatively young for lunar rocks. The radiogenic isotope data from the NWA 773 OC include a ${ }^{147} \mathrm{Sm} /{ }^{143} \mathrm{Nd}$ age of $2.993 \pm 0.032 \mathrm{Ga}$ (Borg et al. 2009), an ${ }^{40} \mathrm{Ar}-{ }^{39} \mathrm{Ar}$ step-heating age of approximately $2.91 \mathrm{Ga}$ (Fernandes et al. 2003), and ${ }^{207} \mathrm{~Pb}-{ }^{206} \mathrm{~Pb}$ analyses of baddeleyite crystals indicating an age of $3.131 \pm 0.012 \mathrm{Ga}$ (Shaulis et al. 2013). The radiogenic ages of NWA 2977 include whole-rock ages of $2.77 \pm 0.04 \mathrm{Ga}$ for Ar-Ar (Burgess et al. 2007), $3.10 \pm 0.05 \mathrm{Ga}$ for $\mathrm{Nd}-\mathrm{Sm}, 3.29 \pm 0.11 \mathrm{Ga}$ for $\mathrm{Rb}-\mathrm{Sr}$ (Nyquist et al. 2009), and 3.12 $\pm 0.01 \mathrm{Ga}$ for $\mathrm{Pb}-\mathrm{Pb}$ baddeleyite (Zhang et al. 2011). Therefore, the similarities in texture, mineralogy, whole-rock geochemistry, and radiogenic age support the inference that NWA 2977 and NWA 773 are paired (Bunch et al. 2006; Nagaoka et al. 2010, 2011; Zhang et al. 2011). Breccias of the NWA 773 clan contain a variety of mafic clasts, including the $\mathrm{OC}$ (Bunch et al. 2006). The OC lithology has one of the youngest crystallization ages among lunar samples collected (e.g., Borg et al. 2009; Nyquist et al. 2009; Zhang et al. 2011). Many of the breccia clasts are considered to be parts of a comagmatic crystallization sequence, with the $\mathrm{OC}$ representing an early stage of magmatic differentiation (Fagan et al. 2003, 2014; Jolliff et al. 2003).

The major objective of this paper is to investigate the formation of NWA 2977 in the context of an evolving lunar magmatic system. One key in the interpretation of its $\mathrm{OC}$ formation conditions is the presence of primary pigeonites inverted to augite and orthopyroxene or inverted pigeonite (Nagaoka et al. 2011). Pyroxene compositions and textures indicate the evolutionary history of their formations based on crystallization temperature, pressure, cooling rate, and melt composition. Pyroxene textures derived from inverted pigeonite have been observed in some samples returned by the Apollo missions (e.g., James et al. 2002; Papike and Bence 1972; Takeda 1973; Takeda and Miyamoto 1977). Inverted pigeonites require slow cooling consistent with crystallization at depths of a few kilometers (Papike and Bence 1972). Such inversion has not been reported in other portions of NWA 2977 and other paired rocks of the NWA 773 clan. In this paper, we report the mineralogy and petrology of NWA 2977, particularly the pyroxene textures and compositions including the inverted pigeonite, to discuss its formation conditions for a better understanding of the lunar igneous activity of the young NWA 773 clan.

\section{Methods}

A 382-mg slice of NWA 2977 was divided into two pieces labeled NWA 297701 and 02. A polished thin section (PTS) labeled PTS 01-1 was prepared from a 179-mg sample NWA 297701 and was examined by using petrographic microscopes (Nagaoka et al. 2010, 2011). A thin section-scale backscattered electron (BSE) image and X-ray elemental maps were obtained by using a JEOL JXA-8900 electron probe microanalyzer (EPMA) at Waseda University. Elemental maps of $\mathrm{Na}, \mathrm{Mg}, \mathrm{Al}, \mathrm{Si}, \mathrm{P}, \mathrm{S}, \mathrm{K}, \mathrm{Ca}, \mathrm{Ti}, \mathrm{Cr}$, and $\mathrm{Fe} \mathrm{K} \alpha$ were collected with a $15-\mathrm{kV}, 5.0 \times 10^{-8} \mathrm{~A}, 1-\mu \mathrm{m}$-diameter electron beam with a $5-\mu \mathrm{m}$ step size. The images were adjusted and combined by using Adobe Photoshop; this program was also used to estimate the modal abundances of minerals from elemental maps covering approximately $10 \times 7 \mathrm{~mm}^{2}$ in PTS 01-1. The quantitative chemical compositions of the minerals in PTS 01-1 were analyzed by using a JEOL JXA-8900 EPMA at the Atmosphere and Ocean Research Institute (AORI), University of Tokyo, with an accelerating voltage of $15 \mathrm{kV}$ and a probe current of $1.2 \times 10^{-8}$ A. All EPMA data reported in this study have analytical totals of $97-103 \mathrm{wt} \%$ and show close fits to the mineral stoichiometries. We used the Bence-Albee method (e.g., Bence and Albee 1968) to correct for interferences and fluorescence. For quantitative analyses, we used well-characterized standards for oxides such as periclase, corundum, rutile, FeO, $\mathrm{MnO}, \mathrm{Cr}_{2} \mathrm{O}_{3}$, and $\mathrm{P}_{2} \mathrm{O}_{5}$ and silicates such as wollastonite, albite, and $\mathrm{K}$-feldspar.

\section{Results and discussion}

Our sample of NWA 2977 consists entirely of an OC dominated by olivine, low-Ca pyroxene, high-Ca pyroxene, and plagioclase, as described initially by Bunch et al. (2006) and in greater detail by Zhang et al. (2011; Fig. 1; Table 1). Almost all of the low$\mathrm{Ca}$ pyroxene in our sample consists of pigeonite, although orthopyroxene was identified in one part of our PTS. Large, juxtaposed, subhedral to euhedral grains of olivine up to $1.0 \mathrm{~mm}$ across with pyroxene and plagioclase filling interstices indicate the cumulus nature of olivine (Fig. 1b, c). Twin lamellae were 


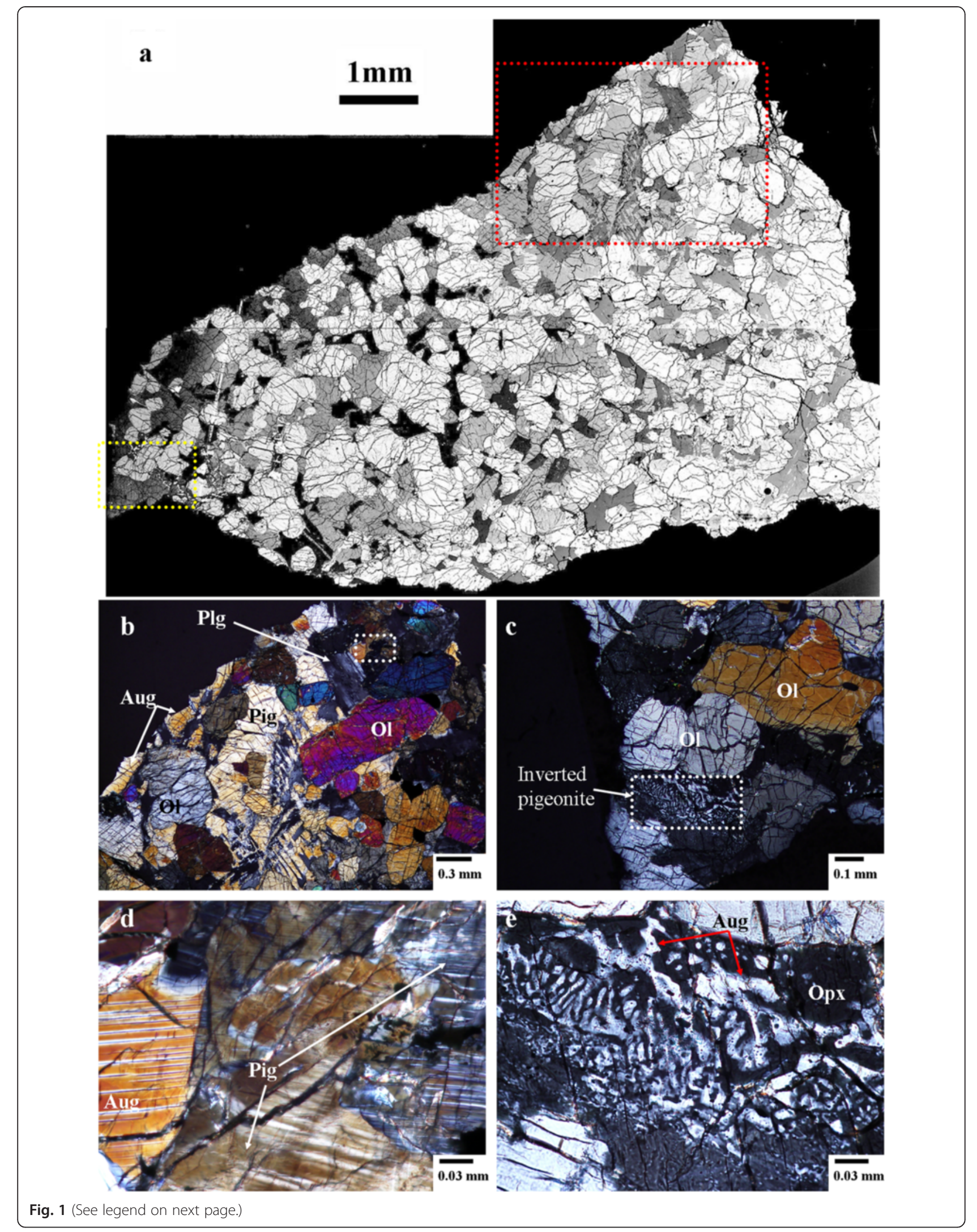


(See figure on previous page.)

Fig. 1 a Backscattered electron (BSE) image of lunar meteorite Northwest Africa (NWA) 2977 from polished thin section (PTS) 01-1. b Detailed textures of minerals surrounded by the red dotted line box in $\mathbf{a}$. $\mathbf{c}$ Detailed textures of minerals surrounded by the yellow dotted line box in a. $\mathbf{d}$ Photomicrograph of exsolution lamellae occurring in some pyroxene grains in NWA 2977 from PTS 01-1, which shows the detailed textures surrounded by the white dotted line box in b. e Photomicrograph of blebby textures of augite in an orthopyroxene (inverted pigeonite) in NWA 2977 from PTS 01-1, which shows the detailed textures surrounded by the white dotted line box in $\mathbf{c}$. Each scale bar represents $1 \mathrm{~mm}$ in $\mathbf{a}, 0.3 \mathrm{~mm}$ in $\mathbf{b}, 0.1 \mathrm{~mm}$ in $\mathbf{c}$, and $0.03 \mathrm{~mm}$ in $\mathbf{d}$ and $\mathbf{e}$. Ol olivine, Pig pigeonite, Opx orthopyroxene, Aug augite, Plg plagioclase

identified in some of the plagioclase grains (Fig. 1b), indicating the preservation of plagioclase crystallinity through shock processing on the lunar surface. Zhang et al. (2011) also reported that this meteorite recorded local shock metamorphism (S3-S6). Our microscopic observations revealed micrometer- to submicrometer-scale exsolution lamellae in pigeonite and augite grains (Fig. 1d). Furthermore, in one part of the sample, we identified blebs of augite distributed with common orientation in the host orthopyroxene (inverted pigeonite), as shown in Fig. 1c, e and Appendix. K-feldspar, Ca-phosphate, troilite, and oxides including ilmenite, $\mathrm{Cr}$-spinel, and baddeleyite are present in the PTS in minor concentrations (Table 1). The K-feldspar crystals occur with Ca-phosphate, ilmenite, and troilite, all as relatively fine crystals in small domains surrounded by coarse-grained mafic silicates and plagioclase. Similar K-feldspar-rich domains in NWA 773 OC have been referred to as intercumulus pockets and are interpreted as products of crystallization from incompatible element-rich residual liquids trapped in the interstices between early formed mafic silicates (e.g., Fagan et al. 2014). For these silicates, the euhedral to subhedral shapes of olivine crystals indicate that olivine crystallized first, followed by pyroxene and plagioclase, which enclosed the olivine. Zhang et al. (2011) reported a similar crystallization sequence of minerals in NWA 2977, although they did not report pyroxene exsolution lamellae.

The modal abundances of our sample of OC are very similar to the abundances obtained by Bunch et al. (2006) from a different sample of NWA 2977 and by Jolliff et al. (2003) from NWA 773 (Table 1). Our sample has less low-Ca pyroxene and more olivine and plagioclase than the NWA 2977 OC studied by Zhang et al. (2011) and has more low-Ca pyroxene and less olivine than the NWA 773 OC studied by Fagan et al. (2003). The differences between these modal abundances are likely attributed at least in part to a heterogeneous distribution of coarse minerals in the OC lithology, as discussed in Zhang et al. (2011).

The mineral compositions obtained by our EPMA analysis are presented in Tables 2 and 3 and are compared with those of Zhang et al. (2011). The olivine grains show a nearly constant $\mathrm{Mg \#}(=$ molar $\mathrm{Mg} /(\mathrm{Mg}+\mathrm{Fe}) \times 100)$ of $69-$ 70 with an average value of 70 . This value is close to the $\mathrm{Mg}$-rich range of OC olivines in NWA 773 analyzed by Fagan et al. (2003) and Jolliff et al. (2003) at Mg\# 66-72 and Mg\# 63-69, respectively. Zhang et al. (2011) reported a Mg\# of 67-70 olivine in their PTS of NWA 2977, which is comparable to our results (Table 2). Our analyses of pigeonite (Mg\# 72-77, average $\left.\mathrm{Wo}_{10} \mathrm{En}_{67} \mathrm{Fs}_{23}\right)$, augite (Mg\# 76-79, average $\mathrm{Wo}_{37} \mathrm{En}_{50} \mathrm{Fs}_{13}$ ), and plagioclase (ranging from $\mathrm{An}_{86}$ to $\mathrm{An}_{94}$ ) are similar to the results reported from the OC of NWA 773 (Fagan et al. 2003, 2014; Jolliff et al. 2003) and from previous work on NWA 2977 (Zhang et al. 2011; Tables 2 and 3). Because submicrometer-scale exsolution lamellae occur in both pigeonite and augite host grains, many of the pyroxene analysis results likely reflect mixtures of high-Ca and low-Ca pyroxene compositions.

In addition to pigeonite and augite, orthopyroxene (average $\mathrm{Wo}_{5} \mathrm{En}_{70} \mathrm{Fs}_{25}$ ) occurs in one part of our PTS. The orthopyroxene hosts varying abundances of

Table 1 Modal abundances (area \%) of minerals in lunar meteorite Northwest Africa (NWA) 2977 and olivine cumulate gabbro (OC) clasts in NWA 773

\begin{tabular}{|c|c|c|c|c|c|c|c|c|}
\hline & Reference & $\mathrm{Ol}$ & $\mathrm{Pig}+\mathrm{Opx}$ & Aug & Plg & $\mathrm{Kfs}$ & Oxide & Phos \\
\hline \multirow[t]{3}{*}{ NWA 2977} & This work & 50 & 25 & 12 & 12 & $\operatorname{Tr}$ & $\operatorname{Tr}$ & $\operatorname{Tr}$ \\
\hline & Bunch $^{a}$ & 51 & 23 & 9 & 14 & - & - & - \\
\hline & Zhang $^{b}$ & 41.1 & 39.1 & 11.9 & 7.1 & 0.1 & 0.5 & 0.2 \\
\hline \multirow[t]{2}{*}{ NWA 773 OC } & Fagan ${ }^{c}$ & 55.5 & 18.9 & 8.7 & 14.2 & 1.6 & 1.2 & $<0.2$ \\
\hline & Jolliff $^{\mathrm{d}}$ & 48 & 29 & 11 & 11 & $\operatorname{Tr}$ & $\operatorname{Tr}$ & $\operatorname{Tr}$ \\
\hline
\end{tabular}

Ol olivine, Pig pigeonite, Opx orthopyroxene, Aug augite, Plg plagioclase, Kfs K-feldspar, Oxide oxide phases, Phos phosphate, $\operatorname{Tr}$ trace amount ${ }^{\mathrm{a}}$ Bunch et al. (2006)

${ }^{\text {b}}$ Zhang et al. (2011)

${ }^{\mathrm{C}}$ Fagan et al. (2003)

dJolliff et al. (2003) 
Table 2 Average mineral compositions of olivine (OI) and plagioclase (PI) grains in lunar meteorite Northwest Africa (NWA) 2977 PTS 01-1 (this work), in comparison with those of Zhang et al. (2011)

\begin{tabular}{|c|c|c|c|c|c|}
\hline \multirow[b]{2}{*}{ Oxide (wt\%) No. } & \multicolumn{2}{|l|}{ This work } & \multicolumn{3}{|c|}{ Zhang et al. (2011) } \\
\hline & Ol 16 & $\mathrm{Pl} 7$ & $\mathrm{Ol}$ & $\mathrm{Pl}$ & $\mathrm{Pl}$ \\
\hline$\overline{\mathrm{SiO}_{2}}$ & $37.72(0.33)$ & $46.16(1.35)$ & 38.1 & 45.0 & 49.4 \\
\hline $\mathrm{TiO}_{2}$ & b.d. & b.d. & 0.08 & & 0.11 \\
\hline $\mathrm{Al}_{2} \mathrm{O}_{3}$ & b.d. & $34.07(0.80)$ & b.d. & 35.2 & 32.3 \\
\hline $\mathrm{Cr}_{2} \mathrm{O}_{3}$ & $0.05(0.02)$ & b.d. & 0.03 & & \\
\hline $\mathrm{FeO}$ & $26.31(0.40)$ & $0.08(0.02)$ & 27.6 & 0.24 & 0.45 \\
\hline $\mathrm{MnO}$ & $0.33(0.06)$ & $0.04(0.02)$ & 0.24 & & \\
\hline $\mathrm{MgO}$ & $34.02(0.26)$ & $0.18(0.07)$ & 33.5 & 0.08 & 0.17 \\
\hline $\mathrm{CaO}$ & $0.11(0.03)$ & $18.04(0.60)$ & 0.15 & 19.1 & 15.7 \\
\hline $\mathrm{Na}_{2} \mathrm{O}$ & b.d. & 0.93(0.33) & b.d. & 0.67 & 1.34 \\
\hline $\mathrm{K}_{2} \mathrm{O}$ & b.d. & $0.17(0.05)$ & b.d. & 0.09 & 1.24 \\
\hline $\mathrm{P}_{2} \mathrm{O}_{5}$ & b.d. & $0.15(0.01)$ & & & \\
\hline Total & 98.54 & 99.82 & 99.6 & 100.4 & 100.7 \\
\hline Mg\# & 70 & & 68 & & \\
\hline An & & 90.6 & & 93.5 & 80.1 \\
\hline $\mathrm{Ab}$ & & 8.4 & & 6.0 & 12.3 \\
\hline Or & & 0.5 & & 0.5 & 7.5 \\
\hline
\end{tabular}

blebs of augite. In one orthopyroxene domain, the blebs of augite are abundant and share a common orientation (Fig. 1c, e; Appendix). Our analyses of the pyroxenes with this texture show that the average chemical composition of the augite blebs is $\mathrm{Mg \#}$ $76, \mathrm{Wo}_{39} \mathrm{En}_{47} \mathrm{Fs}_{14}$, and the average chemical compos-

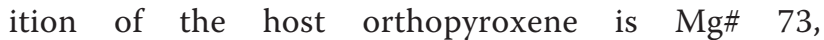
$\mathrm{Wo}_{5} \mathrm{En}_{70} \mathrm{Fs}_{25}$ (Table 3). The bulk chemical composition of this area, with an average $\mathrm{Mg} \#$ of 74 , $\mathrm{Wo}_{15} \mathrm{En}_{63} \mathrm{Fs}_{22}$, gives a Ca-rich pigeonite composition. These results confirm that the texture is inverted pigeonite, which is formed by crystallization from liquid as pigeonite followed by inversion to augite + orthopyroxene during cooling. Thus, the types of pyroxene occurring in PTS 01-1 include (1) augite \pm Ca-poor lamellae (Px 1, 2, 3); (2) pigeonite \pm Ca-rich lamellae (Px 4, 5, 6, 7, 8); (3) orthopyroxene with few augite lamellae (Px 9); and (4) inverted pigeonite (Fig. 1c, e). Figure 2 shows the compositions of Px 1 to Px 9.

Inverted pigeonites have been found in the deepseated Mg-suite norite returned by the Apollo missions, such as the example in breccia 76255 (Takeda and Miyamoto 1977). Inverted pigeonites were also found in clasts in polymictic breccias 14083 (Papike and
Bence 1972) and 15459 (Takeda 1973). However, no inverted pigeonites from Apollo mare basalts have been identified (e.g., Takeda 1973). The occurrence of inverted pigeonite in the deep-seated rocks is consistent with the relatively slow cooling rate required for inversion (e.g., Papike and Bence 1972).

Figure 2 represents compositions of pyroxenes in NWA 2977 PTS 01-1 projected onto quadrilateral isotherms (Sack and Ghiorso 1994). The Ca content of the primary augite suggests crystallization at $1100{ }^{\circ} \mathrm{C}$ to $1000{ }^{\circ} \mathrm{C}$. Three types of pigeonite occur in our PTS: (1) inverted pigeonite (pigI); (2) uninverted pigeonite (pigII for Px 7,8) with exsolution lamellae and a high Mg\# of 77; and (3) uninverted pigeonite (pigIII for Px 4, 5, 6) with exsolution lamellae and a low Mg\# of 72 .

The pigeonite eutectoid reaction (PER) line is the isobaric univariant line on which three phases coexist (Ishii 1975). On the basis of the compositions of such pyroxenes in two lavas of known temperature in Japan, Ishii determined an approximate PER line as $T=$ $1270-480 \times X_{\mathrm{Fe}}$, where $T$ is the temperature in ${ }^{\circ} \mathrm{C}$ and $X_{\mathrm{Fe}}$ is the atomic ratio of $\mathrm{Fe} /(\mathrm{Mg}+\mathrm{Fe})$ of pigeonite prior to inversion. By using the $\mathrm{Fe} /(\mathrm{Mg}+\mathrm{Fe})$ of the inverted pigeonite in NWA 2977, 0.265, a temperature of $1140{ }^{\circ} \mathrm{C}$ was determined. The PER temperatures estimated from each $\mathrm{Mg \#}$ are (1) $T_{\mathrm{I}}=1140{ }^{\circ} \mathrm{C}$ for pigI, (2) $1150{ }^{\circ} \mathrm{C}<T_{\mathrm{II}}<1160{ }^{\circ} \mathrm{C}$ for pigII, and (3) $1130{ }^{\circ} \mathrm{C}<T_{\text {III }}<1140{ }^{\circ} \mathrm{C}$ for pigIII. For the inverted pigeonite (pigI), the crystallization temperature of the primary pigeonite prior to inversion, at $\sim 1200{ }^{\circ} \mathrm{C}$, was slightly higher than its PER temperature of $1140{ }^{\circ} \mathrm{C}$, as shown in Fig. 2. The formation temperature of other pigeonites (uninverted), at $1100{ }^{\circ} \mathrm{C}$, was lower than each PER temperature. The $\mathrm{Ti} / \mathrm{Al}$ ratios of pyroxene indicate a crystallization order of pyroxene followed by plagioclase (e.g., Bence et al. 1970; Fagan et al. 2003; Zhang et al. 2011). Early pyroxenes show $\mathrm{Ti} / \mathrm{Al}$ close to or lower than 0.25 , and late pyroxenes show higher Ti/Al. PigIII shows slightly higher $\mathrm{Ti} / \mathrm{Al}$ ratios, at $0.14-0.32$, than pigII, at 0.06-0.12. PigII crystallized prior to plagioclase, and pigIII crystallized after pigII. The crystallization sequence of pigeonite is consistent with their Mg\# trend including a high Mg\# of 77 for pigII and a low Mg\# of 72 for pigIII. The variations in exsolution patterns of the pyroxenes may reflect subtle variations in the timing of crystallization, the cooling rate from location to location in the rock, and the effects of pyroxene $\mathrm{Mg \#}$ on the inversion temperature.

The similar mineralogy, petrology, trace element composition, and young crystallization age of NWA 2977 and the OC of the NWA 773 clan support their pairing (e.g., Zhang et al. 2011; this work). However, inverted pigeonite has not been identified in other 
Table 3 Average pyroxene compositions in lunar meteorite Northwest Africa (NWA) 2977 polished thin section (PTS) 01-1 (this work), in comparison with the compositional ranges of Zhang et al. (2011)

\begin{tabular}{|c|c|c|c|c|c|c|c|}
\hline \multirow[b]{4}{*}{ No. } & \multicolumn{4}{|l|}{ This work } & \multicolumn{3}{|c|}{ Zhang et al. (2011) } \\
\hline & \multirow[b]{2}{*}{ Pig } & \multirow{3}{*}{$\begin{array}{l}\text { Aug } \\
3\end{array}$} & \multicolumn{2}{|c|}{ Inverted pigeonite } & \multirow{3}{*}{ Pig } & \multirow{3}{*}{ Aug } & \multirow{3}{*}{ Opx } \\
\hline & & & Opx & Aug & & & \\
\hline & 5 & & 6 & 6 & & & \\
\hline \multicolumn{8}{|c|}{ Oxide (wt\%) } \\
\hline $\mathrm{SiO}_{2}$ & $53.91(0.64)$ & $52.12(0.56)$ & $53.88(0.21)$ & $51.92(0.47)$ & $53.7-54.2$ & $51.5-52.4$ & 54.2 \\
\hline $\mathrm{TiO}_{2}$ & $0.33(0.20)$ & $0.94(0.45)$ & $0.48(0.10)$ & $0.72(0.13)$ & $0.17-0.56$ & $0.24-1.68$ & 0.60 \\
\hline $\mathrm{Al}_{2} \mathrm{O}_{3}$ & 1.15(0.19) & $2.15(0.14)$ & $1.20(0.15)$ & $2.03(0.42)$ & $0.83-1.55$ & $2.07-2.28$ & 0.74 \\
\hline $\mathrm{Cr}_{2} \mathrm{O}_{3}$ & $0.51(0.11)$ & $0.85(0.06)$ & $0.42(0.09)$ & $0.70(0.07)$ & $0.19-0.73$ & $0.37-1.01$ & 0.30 \\
\hline $\mathrm{FeO}$ & $14.47(1.24)$ & $9.05(0.60)$ & $16.04(0.46)$ & $8.85(0.63)$ & 13.9-16.7 & $9.21-9.26$ & 17.9 \\
\hline $\mathrm{MnO}$ & $0.29(0.08)$ & $0.22(0.03)$ & $0.31(0.09)$ & $0.23(0.06)$ & $0.28-0.32$ & $0.18-0.22$ & 0.29 \\
\hline $\mathrm{MgO}$ & $23.29(1.39)$ & 16.96(0.64) & $24.06(0.38)$ & $15.85(0.51)$ & $20.6-24.3$ & $15.1-18.5$ & 24.0 \\
\hline $\mathrm{CaO}$ & $4.89(1.12)$ & $16.56(0.63)$ & $2.14(0.08)$ & $17.51(1.07)$ & $3.37-8.10$ & $16.3-18.9$ & 2.09 \\
\hline $\mathrm{Na}_{2} \mathrm{O}$ & b.d. & $0.07(0.01)$ & b.d. & $0.09(0.02)$ & b.d. & $<0.06$ & b.d. \\
\hline $\mathrm{K}_{2} \mathrm{O}$ & b.d. & b.d. & b.d. & b.d. & & & \\
\hline $\mathrm{P}_{2} \mathrm{O}_{5}$ & $0.04(0.01)$ & $0.13(0.01)$ & b.d. & $0.14(0.03)$ & & & \\
\hline Total & 98.88 & 99.05 & 98.53 & 98.04 & & & 100.1 \\
\hline Mg\# & 74 & 77 & 73 & 76 & $71-76$ & $75-78$ & 71 \\
\hline Wo & 10.3 & 36.8 & 4.5 & 39.3 & 7.0-16.8 & $33.1-40.0$ & 4.2 \\
\hline En & 66.9 & 49.7 & 70.0 & 47.0 & $59.8-67.2$ & $44.7-52.4$ & 67.7 \\
\hline Fs & 22.8 & 13.5 & 25.5 & 13.7 & $21.3-27.0$ & $14.5-15.2$ & 28.0 \\
\hline
\end{tabular}

samples of OC from the NWA 773 clan. Jolliff et al. (2003) suggested that NWA 773 OC crystallized with relatively rapid cooling in a shallow magma chamber or a thick ponded flow according to their mineral data such as no resolvable lamellae in the augite. The presence of inverted pigeonite in the Apollo 14 samples 14082 and 14083 indicates slow cooling of the host rock at a depth of several kilometers (Papike and Bence 1972). Therefore, the difference between their OC lithologies could reflect the distinct physical conditions of their crystallization, such as the temperature and cooling rate (e.g., Takeda 1973). The NWA 2977 OC could have

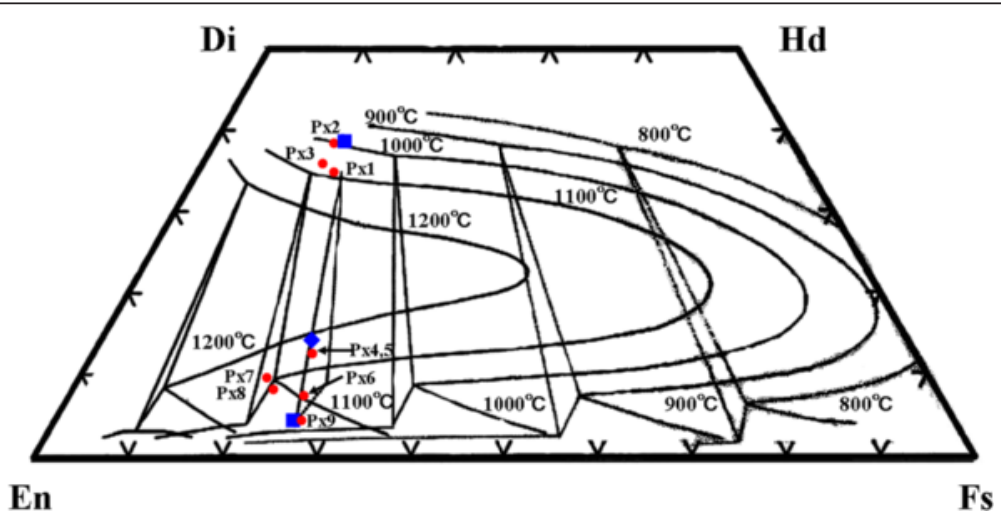

Fig. 2 Compositional variation of pyroxenes in lunar meteorite Northwest Africa (NWA) 2977 from polished thin section (PTS) 01-1 (red circles) projected onto quadrilateral isotherms (Sack and Ghiorso, 1994). The fields were taken from Jolliff et al. (2003). Blue squares represent the average of augite blebs $\left(\mathrm{WO}_{39} \mathrm{En}_{47} \mathrm{Fs} \mathrm{s}_{14}\right)$ and host orthopyroxene $\left(\mathrm{WO}_{5} \mathrm{En}_{70} \mathrm{Fs}_{25}\right)$, and the blue diamond represents the bulk composition of inverted pigeonite $\left(\mathrm{Wo}_{15} \mathrm{En}_{63} \mathrm{Fs}_{22}\right.$; Fig. 1e). Px no. indicates the pyroxene number 
required slower accumulation than the other $\mathrm{OC}$ without inverted pigeonite, which crystallized more rapidly at a shallower depth (e.g., Jolliff et al. 2003). If NWA 2977 and NWA 773 were comagmatic, the relatively high Mg\# of the NWA 2977 OC olivine combined with the occurrence of inverted pigeonite implies that this OC could have formed at an earlier stage of cooling in a deeper level of the OC magmatic body. The reported cosmic ray exposure (CRE) age of NWA 2977, at $12 \mathrm{Ma}$, is younger than that of the NWA 773 cumulate, at $82 \mathrm{Ma}$, suggesting that NWA 2977 had a shorter exposure time on the lunar surface or it originated from a deeper source in the lunar regolith (Burgess et al. 2007). A deeper source in the lunar regolith for NWA 2977 is consistent with our interpretation based on the petrology of NWA 2977 crystallization occurring at a deeper level than the NWA 773 OC.

The slight differences in the $\mathrm{Mg \#}$ of olivine and the cooling histories between OCs of NWA 2977 and the NWA 773 clan imply different crystallization conditions such as timing, crystallization depth, and temperature in the OC magmatic system. As previously discussed, the NWA 773 clan OC is younger than most lunar rocks in the present collection of Apollo and Luna samples and lunar meteorites. The heat source for melting could have been derived from natural radioactive elements in KREEP, as suggested by the incompatible element-rich signatures of all NWA 773 clan samples (e.g., Fagan et al. 2003; Jolliff et al. 2003; Nyquist et al. 2009; Zhang et al. 2011). The NWA 773 clan may be associated with igneous activity at a young age of $\leq 3.0 \mathrm{Ga}$ in the PKT region (e.g., Morota et al. 2011).

\section{Conclusions}

The lunar meteorite NWA 2977 is an OC that shares textural and mineralogical similarities with the olivine cumulate lithology of the NWA 773 clan of meteorites, as noted in previous work (Bunch et al. 2006; Zhang et al. 2011). Various pyroxenes are observed including augite, orthopyroxene, primary pigeonite, and inverted pigeonite. The presence of inverted pigeonite, which requires a slow cooling rate, provides evidence for the NWA 2977 formation from early stage cumulates buried at levels deeper than those for NWA 773 OC, in which inverted pigeonite has not been reported. If NWA 2977 and NWA 773 were comagmatic, the inverted pigeonite and relatively magnesian composition of the olivine in NWA 2977 imply that this rock formed slowly at an earlier stage of crystallization at a deeper level than that of the NWA 773 clan OC.

\section{Appendix}
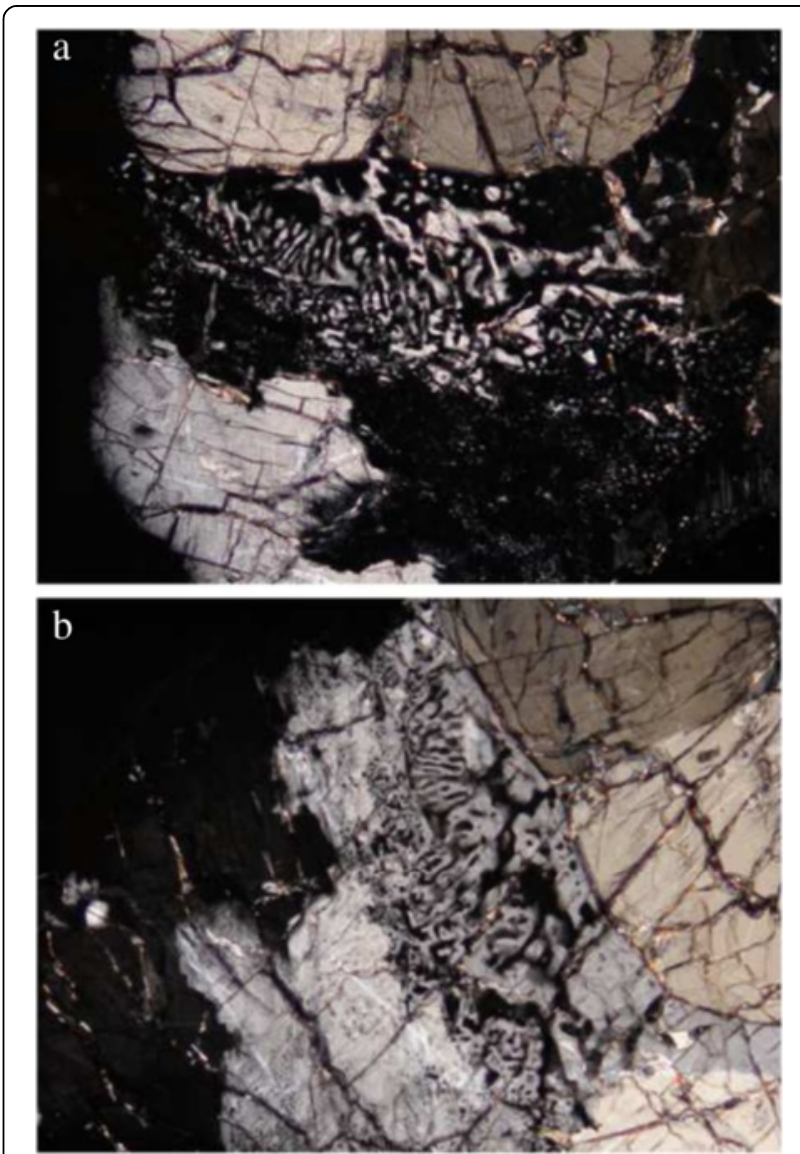

Fig. 3 Photomicrographs of augite blebs captured under cross-polarized light at $\mathbf{a}$ one angle in which all augite blebs are in illuminated and $\mathbf{b}$ that rotated $90^{\circ}$ in which all augite blebs are in extinction

\section{Abbreviations}

BSE: backscattered electron; EPMA: electron probe microanalyzer; NWA: Northwest Africa; OC: olivine cumulate gabbro; PER: pigeonite eutectoid reaction; PTS: polished thin section.

\section{Competing interests}

The authors declare that they have no competing interests.

\section{Authors' contributions}

$\mathrm{HN}$ and $\mathrm{YK}$ designed this study. $\mathrm{HN}$ and $\mathrm{HT}$ performed all the quantitative mineral analyses at AORI. TF and HN collected the thin section-scale BSE images and X-ray elemental maps by using the EPMA at Waseda University. This work was supported by ME and $\mathrm{NH}$. All of the authors read and approved the manuscript.

\section{Acknowledgements}

The sample separation and preparation of the PTS were supported by the National Institute of Polar Research, Tokyo, Japan. EPMA analysis was supported by the cooperative program (2011 No. 107; 2012 No. 108: PI H. Takeda) provided by AORI, University of Tokyo. This work was in part supported by Research Fellowships of the Japan Society for the Promotion of Science for Young Scientists. We greatly appreciate Drs. Yasuo Ogawa and Keiji Ohtsuki and two anonymous reviewers for providing helpful comments and suggestions to improve this manuscript. 


\section{Author details}

${ }^{1}$ Research Institute for Science and Engineering, Waseda University, Shinjuku, Tokyo 169-8555, Japan. ${ }^{2}$ School of Advanced Science and Engineering, Waseda University, Shinjuku, Tokyo 169-8555, Japan. ${ }^{3}$ Institute of Space and Astronautical Science (ISAS), Japan Aerospace Exploration Agency (JAXA), Sagamihara, Kanagawa 252-5210, Japan. ${ }^{4}$ Department of Earth and Planetary Science, University of Tokyo, Hongo, Tokyo 113-0033, Japan. ${ }^{5}$ Department of Earth Science School of Education, Waseda University, Shinjuku, Tokyo 169-8050, Japan. ${ }^{6}$ Department of Chemistry, Tokyo Metropolitan University, Hachioji, Tokyo 192-0397, Japan.

Received: 30 April 2015 Accepted: 28 November 2015

Published online: 12 December 2015

\section{References}

Anand M, Taylor LA, Floss C, Neal CR, Terada K, Tanikawa S (2006) Petrology and geochemistry of LaPaz Icefield 02205: a new unique low-Ti mare-basalt meteorite. Geochim Cosmochim Acta 70:246-264

Bence AE, Albee AL (1968) Empirical correction factors for the electron microanalysis of silicates and oxide. J Geol 76:382-403

Bence AE, Papike JJ, Prewitt CT (1970) Apollo 12 clinopyroxene: chemical trends. Earth Planet Sci Lett 8:393-399

Borg LE, Gaffney AM, Shearer CK, DePaolo DJ, Hutcheon ID, Owens TL, Ramon E, Brennecka G (2009) Mechanisms for incompatible-element enrichment on the Moon deduced from the lunar basaltic meteorite Northwest Africa 032. Geochim Cosmochim Acta 73:3963-3980

Bunch TE, Wittke JH, Korotev RL, Irving AJ (2006) Lunar meteorites NWA 2700, NWA 2727 and NWA 2977: mare basalts/gabbro breccias with affinities to NWA 773. In: Lunar and Planetary Science Conference, 37th edn. Lunar Planet Sci Conf XXXVII, League city TX, Abstract \#1375

Burgess R, Fernandes VA, Irving AJ, Bunch TE (2007) Ar-Ar ages of NWA 2977 and NWA 3160-lunar meteorites paired with NWA 773. In: Lunar and Planetary Science Conference, 38th edn. Lunar Planet. Sci. Conf. XXXVIII, League city TX, Abstract \#1603

Connolly HC, Zipfel J, Grossman JN, Folco L, Smith C, Jones RH, Righter K, Zolensky M, Russell SS, Benedix GK, Yamaguchi A, Cohen BA (2006) The Meteoritical Bulletin, No. 90, 2006 September. Meteorit Planet Sci 41:1383-1418

Fagan TJ, Taylor GJ, Keil K, Hicks TL, Killgore M, Bunch TE, Wittke JH, Mittlefehldt DW, Clayton RN, Mayeda TK, Eugster O, Lorenzetti S, Norman MD (2003) Northwest Africa 773: lunar origin and iron-enrichment trend. Meteorit Planet Sci 38:529-554

Fagan TJ, Kashima D, Wakabayashi Y, Suginohara A (2014) Case study of magmatic differentiation trends on the Moon based on lunar meteorite Northwest Africa 773 and comparison with Apollo 15 quartz monzodiorite. Geochim Cosmochim Acta 133:97-127

Fernandes VA, Burgess R, Turner G (2003) ${ }^{40} \mathrm{Ar}-{ }^{39} \mathrm{Ar}$ chronology of lunar meteorite Northwest Africa 032 and 773. Meteorit Planet Sci 38:555-564

Hiesinger H, Head JW III (2006) New views of lunar geoscience: an introduction and overview. In: Jolliff BL, Wieczorek MA, Shearer CK, Neal CR (eds) New views of the Moon, reviews in mineralogy \& geochemistry, vol 60 . Mineralogical Society America Press, Virginia, pp 1-81

Ishii T (1975) The relations between temperature and composition of pigeonite in some lavas and their application to geothermometry. Min J 8:48-57

James OB, Floss C, McGee JJ (2002) Rare earth element variations resulting from inversion of pigeonite and subsolidus reequilibration in lunar ferroan anorthosites. Geochim Cosmochim Acta 65:1269-1284

Jolliff BL, Gillis JJ, Haskin LA, Korotev RL, Wieczorek MA (2000) Major lunar crustal terranes: surface expressions and crust-mantle origins. J Geophys Res 105 4197-4216

Jolliff BL, Korotev RL, Zeigler RA, Floss C (2003) Northwest Africa 773: lunar mare breccia with a shallow-formed olivine-cumulate component, inferred very-low-Ti (VLT) heritage, and a KREEP connection. Geochim Cosmochim Acta 67:4857-4879

Korotev RL (2005) Lunar geochemistry as told by lunar meteorites. Chem Der Erde 65:297-346

Morota T, Haruyama J, Ohtake M, Matsunaga T, Honda C, Yokota Y, Kimura J, Ogawa Y, Demura H, Iwasaki A, Sugihara T, Saiki K, Nakamura R, Kobayashi S, Ishihara Y, Takeda H, Hiesinger H (2011) Timing and characteristics of the latest mare eruption on the Moon. Earth Planet Sci Lett 302:255-266

Nagaoka H, Karouji Y, Takeda H, Ebihara M, Hasebe N (2010) Chemical signatures in bulk element composition for Northwest Africa 2977. In 73th Annual
Meeting of the Meteoritical Society, New York, 26-30 July 2010. Meteorit Planet Sci 45(Supplement s1):A5-A227, Abstract No. 5183

Nagaoka H, Karouji Y, Takeda H, Fagan TJ, Ebihara M, Hasebe N (2011) Co-existing pyroxenes in the Northwest Africa 2977 with reference to the source region. In: Lunar and Planetary Science Conference, 42nd edn. Lunar Planet Sci Conf XXXXII, the Woodlands, TX, Abstract \#1864

Nagaoka H, Takeda H, Karouji Y, Ohtake M, Yamaguchi A, Yoneda S, Hasebe N (2014) Implications for the origins of pure anorthosites found in the feldspathic lunar meteorites, Dhofar 489 group. Earth Planets Space 66:115. doi:10.1186/1880-5981-66-115

Nyquist LE, Shih C-Y (1992) The isotopic record of lunar volcanism. Geochim Cosmochim Acta 56:2213-2234

Nyquist LE, Shish C-Y, Reese YD, Irving AJ (2009) Sm-Nd and Rb-Sr ages for Northwest Africa 2977, a young lunar gabbro from the PKT. In 72nd Annual Meeting of the Meteoritical Society, Nancy, 13-18 July 2009. Meteorit Planet Sci 44 (Issue S7):A15-A229, Abstract No. 5347

Ohtake M, Takeda H, Matsunaga T, Yokota Y, Haruyama J, Morota T, Yamamoto S, Ogawa Y, Hiroi T, Karouji Y, Saiki K, Lucey PG (2012) Asymmetric crustal growth on the Moon indicated by primitive farside highland materials. Nat Geosci 5:384-388

Papike JJ, Bence AE (1972) Apollo 14 inverted pigeonites: possible samples of lunar plutonic rocks. Earth Planet Sci Lett 14:176-182

Sack RO, Ghiorso MS (1994) Thermodynamics of multicomponent pyroxenes: II. Phase relations in the quadrilateral. Contribut Min Petrol 116:287-300

Shaulis BJ, Righter M, Lapen TJ, Irving AJ (2013) 3.1 Ga crystallization age of magnesian and ferroan gabbro lithologies in lunar meteorites Northwest Africa 773, 3170, 6950, and 7007, and evidence for 3.95 Ga components in NWA 773 polymict breccia (abstract). In: Lunar and Planetary Science Conference, 44th edn. Lunar Planet Sci Conf XLIV, Woodlands TX, Abstract \#1781

Shearer CK, Hess PC, Wieczorek MA, Pritchard ME, Parmentier EM, Borg LE, Longhi J, Elkins-Tanton LT, Neal CR, Antonenko I, Canup RM, Halliday AN, Grove TL, Hager BH, Lee D-C, Wiechert U (2006) Thermal and magmatic evolution of the Moon. In: Jolliff BL, Wieczorek MA, Shearer CK, Neal CR (eds) New views of the Moon, reviews in mineralogy \& geochemistry, vol 60. Mineralogical Society America Press, Virginia, pp 365-518

Spudis PD, Pieters CM (1991) Global and regional data about the Moon. In: Heiken GH, Vaniman DT, French BM (eds) Lunar Sourcebook. Cambridge Univ. Press, New York, pp 595-632

Takeda H (1973) Inverted pigeonites from a clast of rock 15459 and basaltic achondrites. In Lunar Science Conference, 4th edn. Proc. 4th Lunar Sci Conf. Geochim Cosmochim Acta 1, supplement, Houston TX, pp 875-885

Takeda H, Miyamoto M (1977) Inverted pigeonites from lunar breccia 76255 and pyroxene-crystallization trends in lunar and achondritic crusts. In Lunar Science Conference, 8th edn. Proc. 8th Lunar Sci Conf, pp 2617-2626

Wang Y, Hsu W, Guan Y, Li X, Li Q, Liu Y, Tang G (2012) Petrogenesis of the Northwest Africa 4734 basaltic lunar meteorite. Geochim Cosmochim Acta 92:329-344

Zhang A-C, Hsu W-B, Floss C, Li X-H, Li Q-L, Liu Y, Taylor LA (2011) Petrogenesis of lunar meteorite Northwest Africa 2977: constraints from in situ microprobe results. Meteorit Planet Sci 45:1929-1947

\section{Submit your manuscript to a SpringerOpen ${ }^{\odot}$ journal and benefit from:}

- Convenient online submission

$\checkmark$ Rigorous peer review

- Immediate publication on acceptance

- Open access: articles freely available online

- High visibility within the field

- Retaining the copyright to your article

Submit your next manuscript at springeropen.com 